УДК 330.341

\title{
ЗЕЛЁНЫЙ СЕКТОР ЭКОНОМИКИ И ЦИФРОВИЗАЦИЯ: НА ПУТИ К УСТОЙЧИВОМУ РАЗВИТИЮ
}

\author{
Диденко Мария Павловна \\ научный сотрудник \\ Института стран Азии и Африки МГУ
}

\begin{abstract}
Аннотация: представлен анализ понятия «зелёная экономика» и его связи с устойчивым развитием и его компонентами. Рассмотрена роль цифровых технологий с точки зрения реализации ЦУР, а также возможных направлений влияния на зелёную экономику. Сделаны выводы относительно «зелёно-цифрового уклада» в России.
\end{abstract}

Ключевые слова: цифровизация, зелёная экономика, устойчивое развитие, пандемия, коронавирус

\section{GREEN ECONOMY AND DIGITALIZTION: ON ROAD TO SUSTAINABLE DEVELOPMENT}

Didenko Maria Pavlovna

\begin{abstract}
: an analysis of the concept of "green economy" and its relationship with sustainable development and its components is presented. The role of digital technologies in terms of the implementation of the SDGs, as well as possible directions of influence on the green economy, is considered. Conclusions are made regarding the "green-digital paradigm" in Russia.
\end{abstract}

Key words: digitalization, green economy, sustainable development, pandemic, COVID-19

Устойчивое развитие уже давно стоит на повестке дня в самых разных странах мира. Цели устойчивого развития (ЦУР), предложенные $\mathrm{OOH}$, постоянно цитируются и становятся зерном многочисленных политических и экономических программ. Одно из ключевых направлений этого подхода развитие «зелёного» сектора экономики, под которым понимается такая экономическая активность, которая позволит увеличивать благосостояние 


\section{ЦИФРОВИЗАЦИЯ КАК НОВАЯ ПАРАДИГМА РАЗВИТИЯ: ВЫЗОВЫ, ВОЗМОЖНОСТИ И ПЕРСПЕКТИВЫ}

населения и приблизиться к социальной справедливости, не увеличивая экологические риски [1, с. 1]. Таким образом, зелёная экономика, по сути, является «технологией устойчивого развития» [2, с. 12]. Причём инструмент это довольно дорогой с точки зрения необходимого технологического и организационного уровня, что приводит к тому, что хотя все страны хотели бы его применять, соответствующие ресурсы есть в основном только у развитых государств. Этот тезис легко подтверждается с помощи разнообразных рейтингов стран мира по уровню развития зелёной экономики $[3]$.

К зелёной экономике ООН относит 10 секторов: энергетика, лесное и сельское хозяйство, рыболовство; управление водными ресурсами; утилизация и переработка отходов; транспорт, промышленность и туризм. В 2011 г. ЮНЕП прогнозировал, что при инвестировании 2\% мирового ВВП (1 трлн. долларов США в год) к середине века произойдёт мастабное «озеленение» мировой экономики, которая в итоге станет ресурсноэффективной и низкоуглеродной [1, с. 35]. Таким образом, можно сказать, что зелёная экономика является своеобразным мостиком, связывающим экономику и экологию в рамках устойчивого развития.

Если же говорить о третьей составляющей концепции устойчивого развития - социальной - то она может быть соединена с экономикой посредством цифровизации. Стоит сразу оговориться, что дать краткое и однозначное определение этому понятию достаточно сложно, если же говорить обще, то основная характеристика этого процесса - трансформация экономических и социальных связей посредством применения ИКТ. Цифровая экономика делает такие блага, как, например, образование, более доступными широким слоям населения. ЦУР 17.18 указывает на необходимость «высококачественных, актуальных и достоверных данных, дезагрегированных по уровню доходов, гендерной принадлежности, возрасту, расе, национальности, миграционному статусу, инвалидности, географическому местонахождению и другим характеристикам, значимым с учётом национальных условий» [4] как условия достижения устойчивого развития. Учитывая современные демографические показатели и сложность задачи их обработки, подобный запрос не может быть удовлетворён при низкой степени цифровизации.

Если зелёная экономика является основой экологической революции, то цифровизация - новой промышленной революции. В этой связи интересно 


\section{ЦИФРОВИЗАЦИЯ КАК НОВАЯ ПАРАДИГМА РАЗВИТИЯ: ВЫЗОВЫ, ВОЗМОЖНОСТИ И ПЕРСПЕКТИВЫ}

рассмотреть взаимодействие цифровизации и зелёного сектора экономики.

В качестве драйвера развития цифровые технологии обладают особенным преимуществом: их введение возможно в любой отрасли, оно требует сравнительно небольшие объёмы капитала, благодаря ему изменения на рынке происходят очень быстро. Способы воздействия цифровой экономики на зелёную можно разделить на 3 направления:

1) Рост эффективности использования энергии и материалов, подразумевающей увелечение доли используемых возобновляемых источников энергии и сокращение доли токсичных материалов, опасных для экологии и здоровья людей. Для этого необходим мониторинг, как раз осуществляемый посредством цифровых технологий. По оценкам спциалистов, так можно сократить мировой потребление энергии на $30 \%$ [5, c. 11].

2) Предоставление эквивалентов услуг виртуально, сокращение числа физических офисов, перевод бюрократических процедур с бумаги в онлайн.

3) Информирование населения об успехах достигнутых в сфере устойчивого развития и зелёной экономики в частности, представление результатов в формах, мотивирующих людей к экологически осознанному поведению.

Примером соединения воедино всех этих способов может быть строительство и развитие умных городов, использующих возобновляемые источники энергии и другие способы минимизации экологических рисков. Цифровизация как бы создаёт среду, позволяющую зелёному сектору быть более эффективным. Это говорит о возможности создания нового «зелёноцифрового уклада».

При этом интересно, что ни в «Стратегии развития информационного общества Российской Федерации на 2017-2030 годы» [6], ни в национальной программе «Цифровая экономика Российской Федерации» [7] ничего не говорится о роли цифровых технологий в развитии зелёной экономики.

Таким образом, можно сделать вывод, что в России ещё не до конца осознаётся потенциал этой синергии. Положительные сдвиги в этом направлении появились с приходом пандемии Covid-19, которая, например, вынудила осуществить форсированный переход на удалённую работу, в результате чего многие компании увидели, насколько это позволяет сократить издержки без потери качества. Очевидно, что даже при полной отмене всех мер по сдерживанию распространения коронавируса, этот тренд на перевод 


\section{ЦИФРОВИЗАЦИЯ КАК НОВАЯ ПАРАДИГМА РАЗВИТИЯ: ВЫЗОВЫ, ВОЗМОЖНОСТИ И ПЕРСПЕКТИВЫ}

услуг в онлайн не исчезнет, а, следовательно, возможны и изменения на глобальном уровне планирования траектории к достижению устойчивого развития с учётом роли цифровизации в увеличении эффективности зелёной экономики.

\section{Список литературы}

1) UNEP, 2011, Towards a Green Economy: Pathways to Sustainable Development and Poverty Eradication - A Synthesis for Policy Makers, $52 \mathrm{p}$

2) Стратегические ресурсы и условия устойчивого развития Российской Федерации и ее регионов / ред. В.М. Котляков, А.А. Тишков. М.: ИГ РАН, 2014. $166 \mathrm{c.}$

3) Зеленая экономика России - новые инвестиционные возможности. Чистые технологии и устойчивое развитие // Информационный бюллетень. 2017. Вып. 1. Март. Эрнст энд Янг.

4) Цели устойчивого развития ООН. [Электронный ресурс]. - Режим доступа: https://www.un.org/sustainabledevelopment/ru/globalpartnerships/ (дата обращения: 17.05.2021).

5) Rappitsch, Ch. Digital Economy and Sustainability. OIKOS; 2017. $30 \mathrm{p}$

6) Указ Президента РФ от 09.05.2017 №203 «О Стратегии развития информационного общества в Российской Федерации на 2017-2030 годы» [Электронный ресурс]. - Режим доступа: www.consultant.ru (дата обращения: 17.05.2021).

7) Распоряжение Правительства РФ от 28.07.2017 №1632-р «Программа «Цифровая экономика Российской Федерации» [Электронный ресурс]. Режим доступа: www.consultant.ru (дата обращения: 17.05.2021).

() М. П. Диденко, 2021 